\title{
Genetic diversity in a structured family of six generations of ornamental chili peppers (capsicum annuum)
}

Article in Acta horticulturae · June 2015

DOI: $10.17660 /$ ActaHortic.2015.1087.53

\section{CITATION}

1

6 authors, including:

\section{Mayana Nascimento}

Universidade Federal de Viçosa (UFV)

26 PUBLICATIONS 86 CITATIONS

SEE PROFILE

\section{C.H. Bruckner}

Universidade Federal de Viçosa (UFV)

141 PUBLICATIONS 747 CITATIONS

SEE PROFILE
READS

54

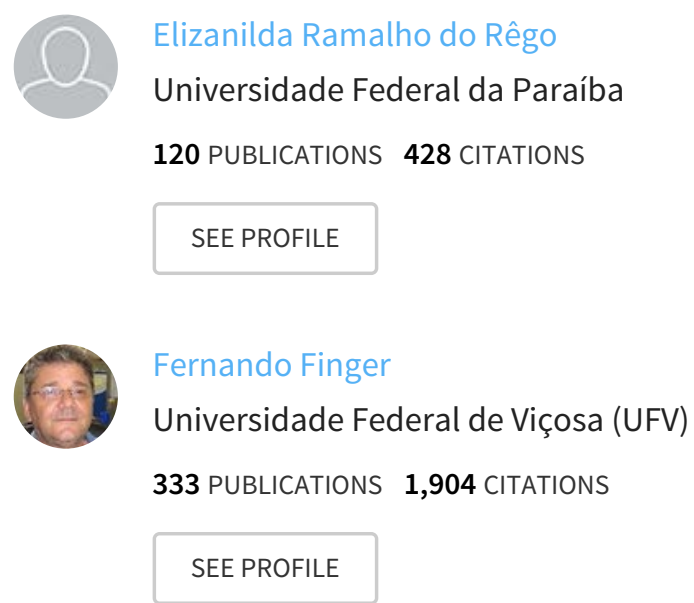

Some of the authors of this publication are also working on these related projects: 


\title{
Genetic Diversity in a Structured Family of Six Generations of Ornamental Chili Peppers (Capsicum annuum)
}

\author{
M.F. Nascimento ${ }^{1}$, N.F.F. Nascimento ${ }^{1}$, E.R. Rêgo ${ }^{2}$, C.H. Bruckner ${ }^{3}$, \\ F.L. Finger ${ }^{3}$ and M.M. Rêgo ${ }^{2}$ \\ ${ }^{1}$ Programa de Pós-Graduação em Genética e Melhoramento, Universidade Federal de \\ Viçosa, Viçosa-MG, Brazil \\ ${ }^{2}$ Centro de Ciências Agrárias, Universidade Federal da Paraíba, Areia Paraíba, Brazil \\ ${ }^{3}$ Universidade Federal de Viçosa, Viçosa-MG, Brazil
}

Keywords: breeding, genetic variability

\begin{abstract}
The genus Capsicum has been used as an ornamental plant, but there are only a few commercial cultivars for this purpose available in Brazil. The aim of this study was to analyze the genetic diversity in a structured family of six generations of ornamental pepper based on quantitative and qualitative data, separately and integrated in the same analysis. These studies are part of the Capsicum breeding program developed at Universidade Federal da Paraíba and Universidade Federal de Viçosa. Six generations $\left(\mathrm{P}_{1}, \mathrm{P}_{2}, \mathrm{~F}_{1}, \mathrm{~F}_{2}, \mathrm{BC}_{1}\right.$, and $\left.\mathrm{BC}_{2}\right)$ of ornamental pepper, belonging to the germplasm bank of Universidade Federal da Paraíba, were evaluated. Two accessions of ornamental pepper plants belonging to the germplasm bank of UFPB (01 and 132) were chosen based on an earlier diallel study. Ten plants of each parent and $F_{1}, 72$ plants of backcross $1\left(B_{1}\right), 75$ plants of backcross $2\left(\mathrm{BC}_{2}\right)$, and 147 plants of the segregating $F_{2}$ generation were studied. Analysis of genetic diversity was performed for all generations. Quantitative data were subjected to cluster analysis by Tocher's method. Multi-traits were analyzed based on the arithmetic complement of the index of coincidence. The matrices of quantitative and multi-categorical traits were summed, and data were subjected to cluster analysis by Tocher's optimized method. The relative importance of the traits was evaluated by Singh (1981)'s method. High genetic variability was determined in $F_{2}$ and backcrosses by three cluster analyses, showing that parents 01 and 132 differ for the evaluated traits. According to the relative importance of traits, those that most contributed to genetic divergence were number of seeds per fruit, number of fruits per plant, days to flowering and days to fruiting.
\end{abstract}

\section{INTRODUCTION}

Peppers of the genus Capsicum are closely related to the Brazilian cultural richness and are a valuable part of the biodiversity patrimony. Cultivars are available with various types, sizes, colors, tastes, and pungency (Neitzke et al., 2008; Nascimento et al., 2012). This diversity can be used as basis for breeding programs for ornamental purposes (Rêgo et al., 2003).

Ornamental peppers such as those cultivated in pots or gardens are widely marketed and available all year long in Brazil (Rêgo et al., 2010), where few studies have been conducted on ornamental pepper regarding the factors of generation of variability and selection (Nascimento et al., 2011). The development of a new cultivar with good pot harmony and size is one of the main objectives of any ornamental-pepper breeding program (Rêgo et al., 2009b).

The existing genetic diversity in a population enables the selection of genetically distant parents for crossing. By doing this, one can produce a strong heterotic effect in the $F_{1}$ progeny and obtain genetic variability in segregating generations (Oliveira et al., 1998; Rêgo et al., 2011b). The study of genetic diversity through genotype-clustering techniques allows for the identification of the degree of similarity or dissimilarity among them (Alvares, 2011). In addition it is possible to use this germplasm in breeding programs (Deshpande et al., 1988; Rêgo et al., 2003). 
The objective of this work was to study the genetic variability through multivariate techniques of a structured population of 6 generations of ornamental pepper belonging to the Horticulture Germplasm Bank of Universidade Federal da Paraíba, aiming to use them in the breeding program of pepper plants for ornamental purposes.

\section{MATERIALS AND METHODS}

Two accessions (01 and 132) of ornamental pepper Capsicum annuum L. belonging to BGH-UFPB (Active Horticulture Germplasm of Universidade Federal da Paraíba) were chosen based on a diallel study and for their good potential for obtaining pepper with desirable traits related to size, yield and earliness (Nascimento et al., 2014). The following 6 generations were evaluated: $P_{1}$ (01), $P_{2}$ (132), $F_{1}$ (first hybrid generation), $\mathrm{F}_{2}$ (first generation from self-pollination), $\mathrm{BC}_{1}$ (backcross $1=\mathrm{F}_{1} \times \mathrm{P}_{1}$ ), and $\mathrm{BC}_{2}$ (backcross $2=\mathrm{F}_{1} \times \mathrm{P}_{2}$ ).

The parents $\left(\mathrm{P}_{1}\right.$ and $\left.\mathrm{P}_{2}\right)$, their progenies $\left(\mathrm{F}_{1}\right)$, segregating generation $\left(\mathrm{F}_{2}\right)$ and backcrosses $\left(\mathrm{BC}_{1}\right.$ and $\left.\mathrm{BC}_{2}\right)$ were seeded in 200-cell styrofoam trays containing a commercial substrate. Seedlings were transplanted to $900-\mathrm{ml}$ pots. Ten plants from each parent $\left(\mathrm{P}_{1}\right.$ and $\left.\mathrm{P}_{2}\right), 10 \mathrm{~F}_{1}$ plants, 72 backcross 1 plants $\left(\mathrm{BC}_{1}\right), 75$ backcross 2 plants $\left(\mathrm{BC}_{2}\right)$, and 147 plants in segregating generation $\mathrm{F}_{2}$ were characterized.

The morpho-agronomic characterization was based on the list of descriptors suggested by IPGRI (1995). Twenty-two (22) qualitative and 19 quantitative descriptors were used. The following quantitative traits were evaluated: plant height, crown diameter, height at the first bifurcation, stem diameter, leaf length, leaf width, corolla length, petal diameter, anther length, style length, days to flowering, fruit weight, fruit length, fruit diameter, pedicel length, pericarp thickness, placental length, fruit dry matter, dry matter content, number of seeds per fruit, number of fruits per plant, and days to fruiting.

The following qualitative descriptors were evaluated: stem pubescence, presence of anthocyanin in the node, leaf color, leaf shape, branching density, growth habit, corolla color, position of the flower, number of flowers per axilla, anther color, style color, color of the fruit in intermediate stage, color of ripe fruit, anthocyanin spots, fruit shape, fruit apex shape, persistence of the fruit on the pedicel, and persistence of pedicel on rachis.

For the analysis of diversity of the 19 multi-categorical traits, a dissimilarity matrix was generated based on the arithmetic complement of the coincidence index. Standardized Euclidean distance was used for the 22 quantitative descriptors.

Three dissimilarity matrices were generated. The first for quantitative data only, the second for multi-trait descriptors only, and the third matrix was the sum of dissimilarity matrices of both descriptors.

Based on the information of the generated dissimilarity matrices, the accessions were clustered by Tocher's optimization method. The relative importance of the quantitative traits was determined using Singh (1981)'s method. All statistical analyses were performed using the GENES computer software (Cruz, 2006).

\section{RESULTS AND DISCUSSION}

Based on the multi-categorical traits, the 324 genotypes referring to the 6 generations $-\mathrm{P}_{1}, \mathrm{P}_{2}, \mathrm{~F}_{1}, \mathrm{~F}_{2}, \mathrm{BC}_{1}$, and $\mathrm{BC}_{2}$ - were separated into three distinct groups. The group one was formed by parent $01\left(\mathrm{P}_{1}\right)$; group two by parent $132\left(\mathrm{P}_{2}\right)$; and group three by the hybrid $\left(\mathrm{F}_{1}\right)$. The other individuals were dispersed among the 90 remaining groups (data not shown). In a segregating $F_{2}$ population of $C$. annuum, Rêgo et al. (2012), presented the formation of five distinct groups based on 11 multi-categorical traits, claiming there was genetic variability in generation $F_{2}$. This was useful to continue with the breeding program of ornamental peppers aiming to obtain new lines. Multi-categorical traits have a great advantage regarding quantitative variables in that they are easy to observe and require less time and labor, which facilitates the breeder's work (Bento et al., 2007).

Using the standardized Euclidean distance as a dissimilarity measure only for the 22 quantitative traits, the 324 genotypes were clustered into 50 different groups, wherein 
the parents and the hybrid were gathered in distinct groups (data not shown). Barroso et al. (2012) and Silva Neto et al. (2014), working with segregating generations of Capsicum annuum, demonstrated that there is a significant variability among them. The variability found within and between species is important for the development of new cultivars of peppers as well as enrichment of the genetic resources of this genus (Rêgo et al., 2011a) and its use in breeding programs.

When the two matrices of the quantitative and multi-categorical data of the 324 genotypes were summed, 75 different groups were formed (data not shown). The result of this analysis was similar to that found in the individual analysis for the multicategorical and quantitative traits. According to Gonçalves et al. (2008) and Tsivelikas et al. (2009), a combined analysis of the quantitative and qualitative data can provide better understanding of the genetic diversity in the germplasm bank and a more comprehensive characterization of the genotype, thus contributing to determine future breeding strategies.

According to the relative importance of the 22 quantitative traits, the traits that most contributed to genetic diversity were: number of seeds per fruit (13.44\%), number of fruits per plant (47.34), days to flowering (13.90\%) and days to fruiting $(17.97 \%)$. Summed up, these traits accounted for $92.66 \%$ of the detected variability. The trait that contributed the least was pericarp thickness, with $0.0001 \%$ (Table 1). According to Rêgo et al. (2003), the variables that contributed with a very low percentage or which did not contribute to the detected variability can be discarded in subsequent studies of genetic diversity of the analyzed population.

Considering only the traits that most contributed to the genetic diversity, the plants with a greater number of seeds per fruit were plant 5 , belonging to generation $\mathrm{F}_{1}$, and plants $1,35,44,47,43,37,49,48$ and 39 , from segregating generation $F_{2}$, as the number of seeds varied between 60 and 70 (Fig. 1).

The plants $2,5,7,8,16,17,20,23,27$ and 44 , all belonging to segregating generation $\mathrm{F}_{2}$ showed the greatest number of fruits per plant, ranging from 95 to 149 fruit per plant (Fig. 2).

For the traits days to flowering and days to fruiting, the earliest plants for flowering and fruiting were plant 28, belonging to generation $\mathrm{F}_{2}$; plants 18, 20, 21 and 22, from $\mathrm{BC}_{1}\left(\mathrm{~F}_{1} \times 01\right)$; and plants $1,5,14,16,24$, belonging to $\mathrm{BC}_{2}\left(\mathrm{~F}_{1} \times 132\right)$ (Fig. 3$)$.

\section{CONCLUSIONS}

Selection can be done within segregating generations and backcrosses for the characteristics number of seeds per fruit, number of fruits per plant, days to flowering and days to fruiting. Results will be further used to continue with the Breeding Program of Ornamental Peppers.

\section{ACKNOWLEDGEMENTS}

The authors are grateful to CNPq and CAPES for financial support for projects.

\section{Literature Cited}

Alvares, R.C. 2011. Divergência genética entre acessos de Capsicum chinense Jacq. coletados no sudoeste goiano. p.59. Diss. Mestrado em Agronomia (Produção vegetal) - Universidade Federal do Goiás.

Barroso, P.A., Rêgo, E.R., Rêgo, M.M., Nascimento, K.S., Nascimento, N.F.F., Nascimento, M.F., Soares, W.S., Ferreira, K.T.C. and Otoni, W.C. 2012. Analysis of segregating generation for components of seedling and plant height of pepper (Capsicum annuum) for medicinal and ornamental purposes. Acta Hort. 953:269-275.

Bento, C.S., Sudre, C.P., Rodrigues, R., Riva, E.M. and Pereira, M.G. 2007. Descritores qualitativos e multicategóricos na estimativa da variabilidade fenotípica entre acessos de pimentas. Scientia Agraria 8:149-156.

Cruz, C.D. 2006. Programa genes: aplicativo computacional em genética e estatística. Viçosa, UFV 648.

Deshpande, A.A., Anand, N. and Ramachander, P.R. 1988. Ideotype differentiation of 
horticultural groups in Capsicum spp. Genet. Agraria 42:357-364.

Gonçalves, L.S.A., Rodrigues, R., Amaral Júnior, A.T., Karasawa, M. and Sudré, C.P. 2008. Comparison of multivariate statistical algorithms to cluster tomato heirloom accessions. Genet. Mol. Res. 7:1289-1297.

IPGRI. 1995. Descriptores para Capsicum (Capsicum spp). Roma: IPGRI. 51.

Nascimento, N.F.F., Rêgo, E.R., Nascimento, M.F., Finger, F.L., Bruckner, C.H. and Rêgo, M.M. 2014. Combination ability for yield and fruit quality in pepper (Capsicum annuum). Genet. Mol. Res. 13:3237-3249.

Nascimento, N.F.F., Rêgo, E.R., Rêgo, M.M., Nascimento, M.F. and Alves, L.I.F. 2012. Compatibilidade em cruzamentos intra e interespecíficos em pimenteiras ornamentais. Rev. Brasil. Hort. Orn. 18:58-62.

Nascimento, N.F.F., Nascimento, M.F., Rêgo, E.R., Rêgo, M.M. and Silva Neto, J.J. 2011. Caracterização morfoagronômica em híbridos interespecíficos de pimenteiras ornamentais. In: Congresso Brasileiro de Olericultura, 51. Anais. Viçosa: AB. 29322939.

Neitzke, R.S., Barbieri, R.L., Heiden, G. and Castro, C.M. 2008. Divergência genética entre variedades locais de Capsicum baccatum utilizando caracteres multicategóricos. Magistra, Cruz das Almas-BA 20:249-255.

Oliveira, V.R., Scapim, C.A. and Casali, V.W.D. 1998. Diversidade genética e eficiência da predição do comportamento. Acta Scientia 20:263-267.

Rêgo, E.R., Santos, R.M.C., Rêgo, M.M., Nascimento, N.F.F., Nascimento, M.F. and Bairral, M.A. 2012. Quantitative and multicategoric descriptors for phenotypic variability in a segregating generation of ornamental peppers. Acta Hort. 937:289-296.

Rêgo, E.R., Finger, F.L., Nascimento, N.F.F., Araújo, E.R. and Sapucay, M.J.L.C. 2011 a. Genética e melhoramento de pimenteiras. p.117-136. In: E.R. Rêgo, F.L. Finger and M.M. Rêgo (eds.), Produção, Genética e Melhoramento de Pimentas (Capsicum spp.). 1 ed. Imprima. Recife, Pernambuco.

Rêgo, E.R., Rêgo, M.M., Cruz, C.D., Finger, F.L. and Casali, V.W.D. 2011b. Phenotypic diversity, correlation and importance of variables for fruit quality and yield traits in Brazilian peppers (Capsicum baccatum). Genet. Resour. Crop Evol. 58:909-918.

Rêgo, E.R., Finger, F.L., Rêgo, M.M., Nascimento, N.F., Nascimento, M.F. and Santos, R.M.C. 2010. Programa de melhoramento de pimenteiras ornamentais da Universidade Federal da Paraíba e Universidade Federal de Viçosa. Hort. Brasil. 28:S2406-S2412.

Rêgo, E.R., Rêgo, M.M., Silva, D.F., Cortez, R.M., Sapucay, M.J.L.C., Silva, D.R. and Silva Junior, S.J. 2009b. Selection for leaf and plant size and longevity of ornamental peppers (Capsicum spp.) grown in greenhouse condition. Acta Hort. 829:71-375.

Rêgo, E.R., Rêgo, M.M., Cruz, C.D., Finger, F.L. and Amaral, D.S.S.L. 2003. Genetic diversity analysis of peppers: a comparison of discarding variables methods. Crop Breed. Appl. Biotechnol. 3:19-26.

Silva Neto, J.J., Rêgo, E.R., Nascimento, M.F., Silva Filho, V.A.L., Almeida Neto, J.X. and Rêgo, M.M. 2014. Variabilidade em população base de pimenteiras ornamentais (Capsicum annuum L.). Rev. Ceres 61:84-89.

Singh, D. 1981. The relative importance of characters affecting genetic divergence. Indian J. Genet. Plant Breed. 1:237-245.

Tsivelikas, A.L., Koutita, O., Anastasiadou, A., Skaracis, G.N., Traka-Mavrona, E. and Koutsika-Sotiriou, M. 2009. Description and analysis of genetic diversity among squash accessions. Brazil. Arch. Biol. Techn. 52:271-283. 


\section{Tables}

Table 1. Relative contribution of the 22 quantitative traits to genetic divergence in ornamental peppers (Capsicum annuum) by Singh (1981)'s method.

\begin{tabular}{lclc}
\hline Trait & $\begin{array}{c}\text { Relative } \\
\text { importance (\%) }\end{array}$ & Trait & $\begin{array}{c}\text { Relative } \\
\text { importance (\%) }\end{array}$ \\
\hline Plant height & 1.9191 & Fruit length & 0.0403 \\
Crown width & 1.8764 & Fruit width & 0.0020 \\
Height at the first bifurcation & 0.7471 & Petiole length & 0.0055 \\
Stem diameter & 0.0011 & Pericarp thickness & 0.0001 \\
Leaf length & 0.1337 & Placental length & 0.0176 \\
Leaf width & 0.0153 & Fruit dry matter content & 2.5579 \\
Corolla length & 0.0021 & Fruit dry matter & 0.0003 \\
Petal diameter & 0.0010 & Number of seeds per fruit & 13.4412 \\
Anther length & 0.0002 & Number of fruits per plant & 47.3427 \\
Style length & 0.0003 & Days to flowering & 13.9054 \\
Fruit weight & 0.0185 & Days to fruiting & 17.9721 \\
\hline
\end{tabular}

\section{Figures}
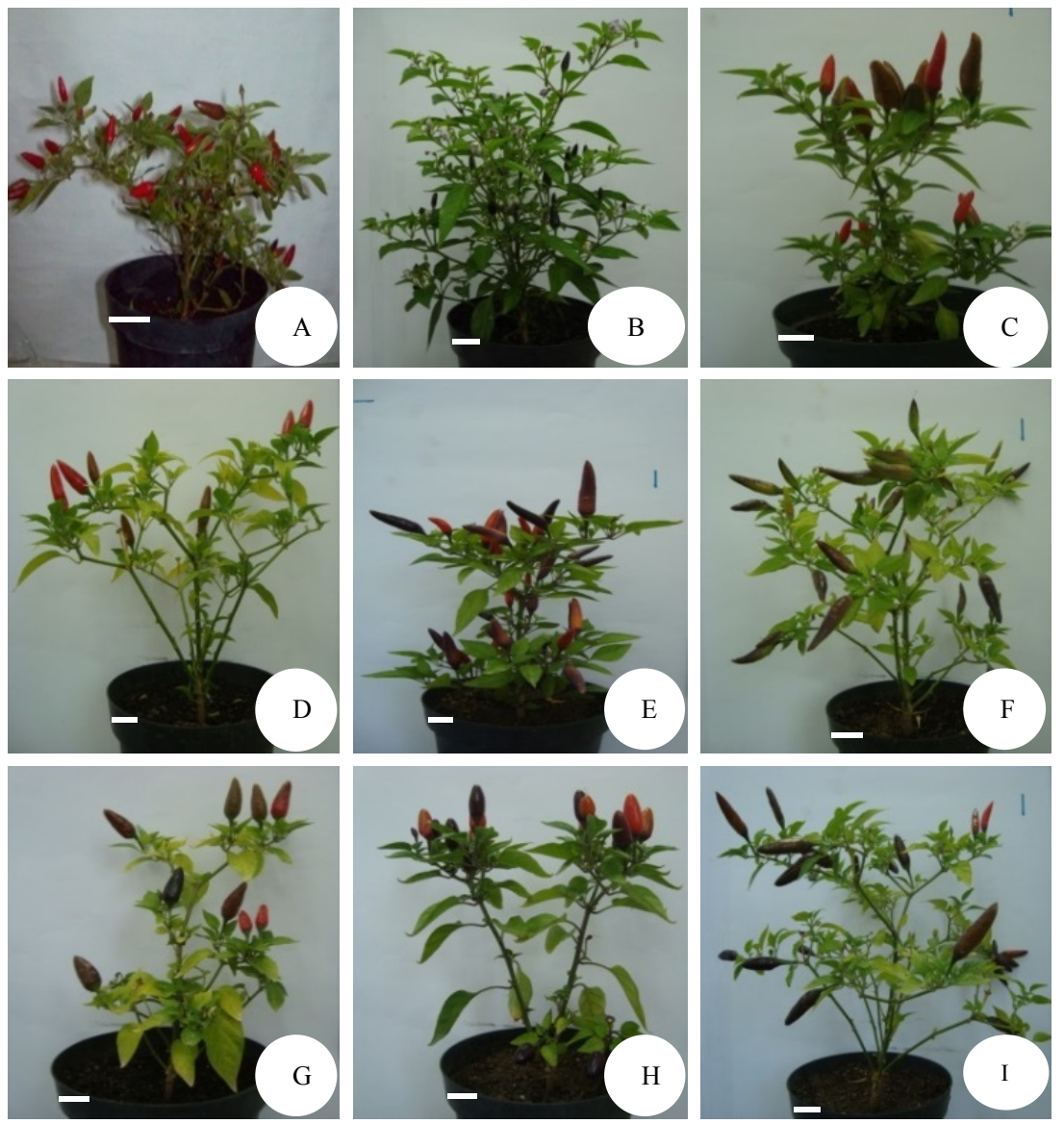

Fig. 1. Different phenotypic classes with larger number of seeds per fruit observed in ornamental peppers $($ Capsicum annuum $) . \mathrm{A}=($ Hybrid $01 \times 132) ; \mathrm{B}=$ Genotype 1 $\left(\mathrm{F}_{2}\right) ; \mathrm{C}=$ Genotype $35\left(\mathrm{~F}_{2}\right) ; \mathrm{D}=$ Genotype $37\left(\mathrm{~F}_{2}\right) ; \mathrm{E}=$ Genotype $39\left(\mathrm{~F}_{2}\right) ; \mathrm{F}=$ Genotype $43\left(\mathrm{~F}_{2}\right) ; \mathrm{G}=$ Genotype $44\left(\mathrm{~F}_{2}\right) ; \mathrm{H}=$ Genotype $47\left(\mathrm{~F}_{2}\right) ; \mathrm{I}=$ Genotype 49 $\left(\mathrm{F}_{2}\right)$. Bars $=1 \mathrm{~cm}$. 

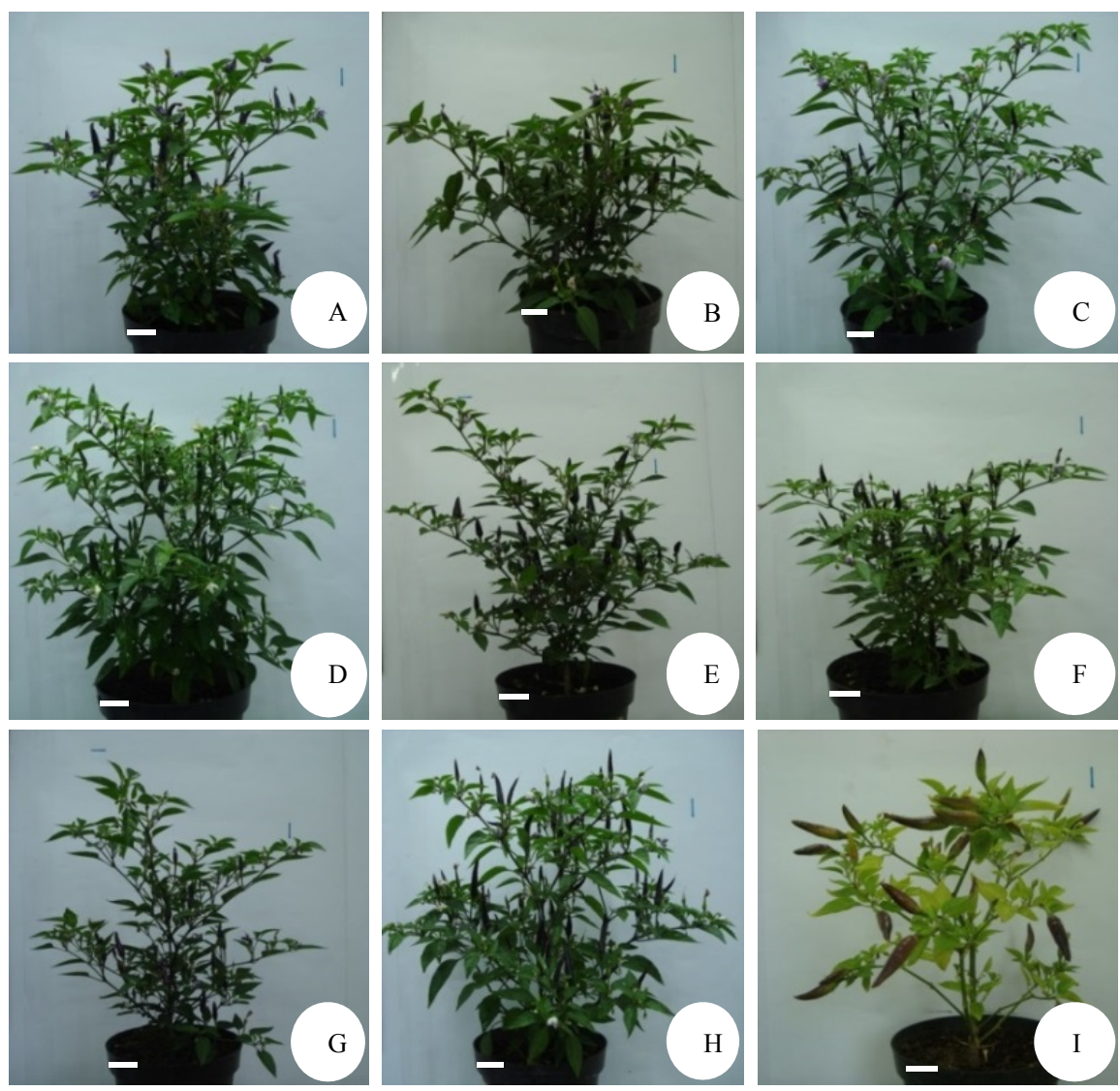

Fig. 2. Different phenotypic classes with larger number of fruits per plant observed in ornamental peppers (Capsicum annuum). $\mathrm{A}=$ Genotype $2\left(\mathrm{~F}_{2}\right) ; \mathrm{B}=$ Genotype 7 $\left(\mathrm{F}_{2}\right) ; \mathrm{C}=$ Genotype $8\left(\mathrm{~F}_{2}\right) ; \mathrm{D}=$ Genotype $16\left(\mathrm{~F}_{2}\right) ; \mathrm{E}=$ Genotype $17\left(\mathrm{~F}_{2}\right) ; \mathrm{F}=$ Genotype $20\left(\mathrm{~F}_{2}\right) ; \mathrm{G}=$ Genotype $23\left(\mathrm{~F}_{2}\right) ; \mathrm{H}=$ Genotype $27\left(\mathrm{~F}_{2}\right) ; \mathrm{I}=$ Genotype 44 $\left(\mathrm{F}_{2}\right)$. Bars $=1 \mathrm{~cm}$. 

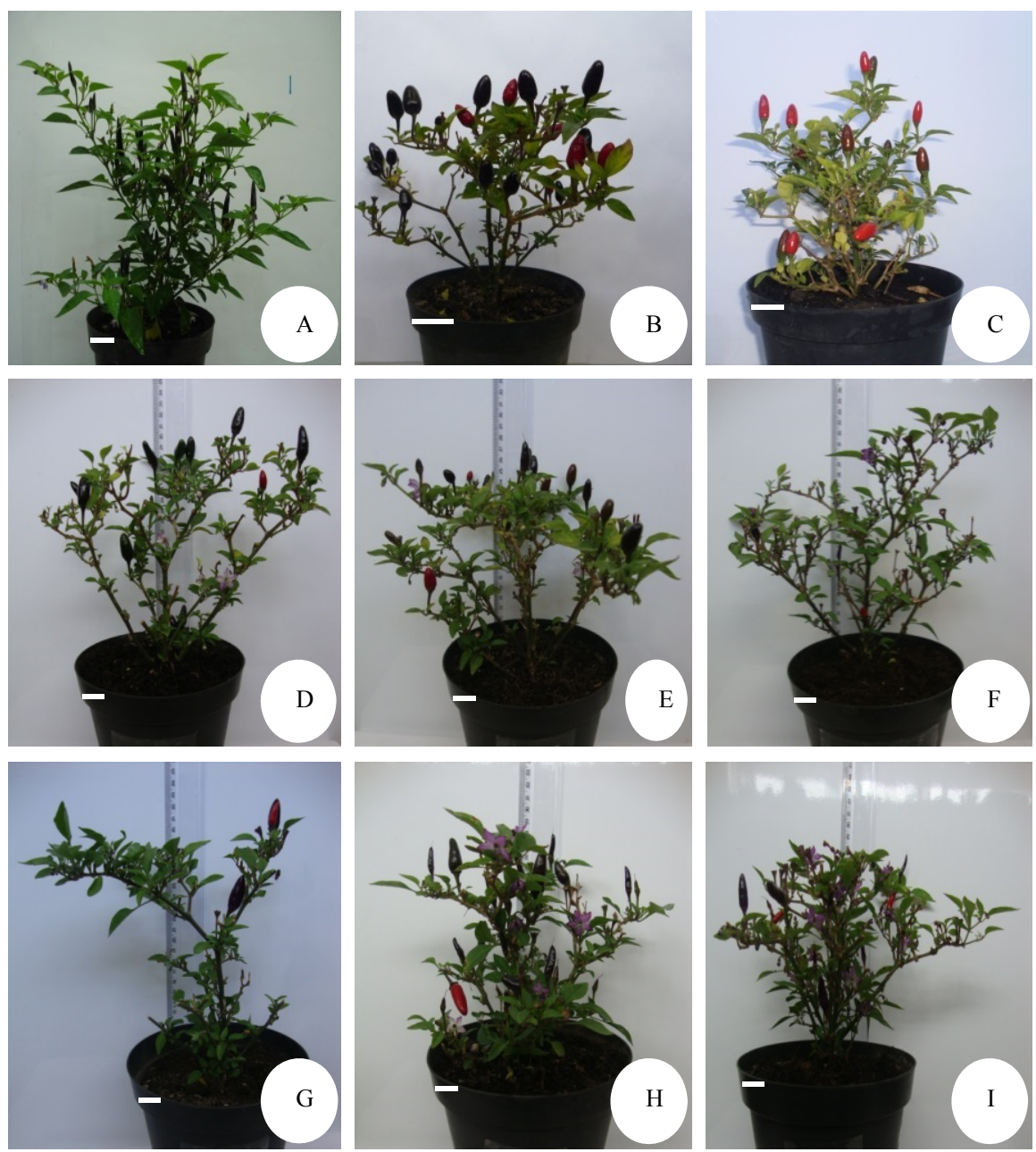

Fig. 3. Different phenotypic classes for the traits days to flowering and days to fruiting in ornamental peppers (Capsicum annuum). $\mathrm{A}=$ Genotype $28\left(\mathrm{~F}_{2}\right) ; \mathrm{B}=$ Genotype 18 $\left(\mathrm{BC}_{1}\right) ; \mathrm{C}=$ Genotype $20\left(\mathrm{BC}_{1}\right) ; \mathrm{D}=$ Genotype $21\left(\mathrm{BC}_{1}\right) ; \mathrm{E}=$ Genotype $22\left(\mathrm{BC}_{1}\right)$; $\mathrm{F}=$ Genotype $1\left(\mathrm{BC}_{2}\right) ; \mathrm{G}=$ Genotype $5\left(\mathrm{BC}_{2}\right) ; \mathrm{H}=$ Genotype $14\left(\mathrm{BC}_{2}\right) ; \mathrm{I}=$ Genotype $16\left(\mathrm{BC}_{2}\right)$. Bars $=1 \mathrm{~cm}$. 
